\title{
Non-Timber Forest Products and their Role in the Livelihoods of People of Nepal: A Critical Review
}

\author{
Sami Shrestha ${ }^{1 *}$, Jiban Shrestha ${ }^{2}$, Kabita Kumari Shah ${ }^{3}$ \\ ${ }^{1}$ Institute of Forestry, Tribhuvan University, Hariyokharka, Pokhara-15, Nepal \\ ${ }^{2}$ Nepal Agricultural Research Council, Agriculture Botany Division, Khumaltar, Lalitpur, Nepal \\ ${ }^{3}$ Gokuleshwor Agriculture and Animal Science, Tribhuvan University, Baitadi, Nepal \\ *Corresponding author (Email: sanusht.iof@gmail.com) | ORCID: 0000-0001-5452-0093
}

How to cite this paper: Shrestha, S., Shrestha, J. and Shah, K.K. (2020). NonTimber Forest Products and their Role in the Livelihoods of People of Nepal: A Critical Reviews. Grassroots Journal of Natural Resources, 3(2): 42-56. Doi: https://doi.org/10.33002/nr2581.6853.03024

Received: 17 May 2020

Reviewed: 26 May 2020

Provisionally Accepted: 30 May 2020

Revised: 02 June 2020

Finally Accepted: 11 June 2020

Published: 22 June 2020

Copyright $\odot 2020$ by author(s)

This work is licensed under the Creative Commons Attribution International License (CC BY 4.0).

http://creativecommons.org/licenses/by/4.0/

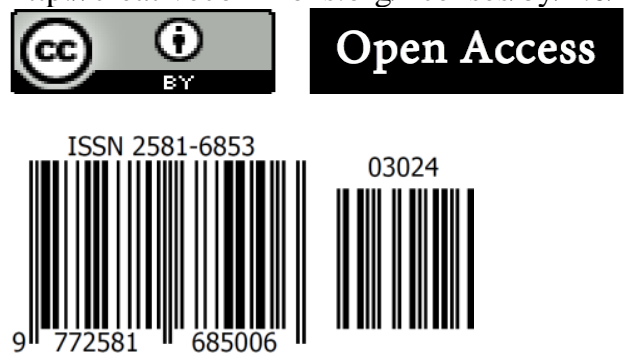

\section{Abstract}

Nepal is a rich source of Non-Timber Forest Products (NTFPs) in terms of production and trading practices. The altitudinal and climatic variations in various pockets of Nepal have contributed to their diversity. This article attempts to outline the current status of NTFPs and its importance in the Nepalese economy. NTFPs provide rural people with food, medicine, construction materials, and income. About $80 \%$ of the rural population depend on the NTFPs for their livelihood and Nepal. NTFPs have commercial, socioeconomic and environmental values in rural communities. More than 700 species of plants are recognized as producing NTFPs and about 150 species of these are commonly used in international trade. The management of NTFPs has been receiving increasing attention from donors, development agencies and user groups who are involved in different aspects of NTFP promotion. Sustainable exploitation, use, and commercialization of NTFPs are important for socioeconomic development, poverty reduction, and livelihood enhancement of rural people in Nepal.

\section{Keywords}

NTFPs, Livelihood, Medicinal and aromatic plants, Revenue, Nepal 
Doi: https://doi.org/10.33002/nr2581.6853.03024

\section{Introduction}

Non-timber forest products (NTFPs) are the products that are derived from forests other than timber (Ahenkan and Boon, 2011). NTFPs have recently been considered an important forest product, but for rural communities. These products have always been an important life support system (Chandrashekharan, 1998; Giri, Bhattacharya and Santra, 2001). NTFPs have importantly been cited as a significant forest product. Angelsen et al. (2014) and Shackleton and Pullanikkatil (2018) showed that NTFPs have been widely known to lead to the wellbeing of several rural and urban households and communities worldwide in different forms. Cocks and Wiersum (2003), Cocksedge (2006) and Endamana et al. (2016) reported that NTFPs are critical to the functioning, security, and reduction of subsistence, particularly for people residing in forest areas. For diverse ethnic groups all over the world, they have important cultural values and significance. NTFP revenue shares are ranging from just few percent to over 50\% in and between regions and communities (Vedeld et al., 2007; Angelsen et al., 2014).

The geography and climatic conditions of Nepal are diverse, resulting in rich biodiversity. There are 11,971 flora recorded in Nepal, accounting for 3.2\% of the total flora of the world (GoN, 2014). Plant species have various medicinal values. Nepal is rich in NTFPs species. In Nepal 700 plant species are medicinal, 440 are wild foods, 30 are spices, and other 71 are fibers yielding (Subedi et al., 2014). Nepal has many bio-resources and is well-known for its remarkable group forestry strategies to forest management (Paudel, 2014; Paudel, 2015); its potential to contribute to the country's economic growth is still insufficient. The commercial, socioeconomic and environmental values of NTFPs are in existence. In Nepal, the NTFP sector is stagnating behind and contributes substantially to the national and local economies. Banjade (2012) reported that the forestry sector in Nepal was not exploiting its maximum potential. The NTFPs culture and development system is the core initiative for the Nepal Planning Commission (2015 to 2017). Comparably, the Forest Sector Policy (2015) demonstrates the contribution of NTFP manufacturing to rural livelihood and directs more to research and study. About $80 \%$ of the developing country's population relies on NTFPs in terms of basic health, nutritional requirements, and the generation of income (FAO, 1995).

NTFPs play an essential role in foreign exchange earnings, which is especially crucial for most developed countries, such as Nepal. The NTFPs for revenue generation were the primary priority of MPFS (Master Plan for Forestry Sector) (1988). In addition, NTFPs make a substantial contribution to poor people's health care by their medicinal and food values. The annual harvest and trading of NTFPs in Nepal in the Indian and overseas markets (approximately $90 \%$ as its raw material) of roughly 10,000-15,000 tons of NTFP, made up by more than 100 species, is around US\$ 8.6 million, approximately six times the official value in timber exports to India (Edward, 1996). The NTFPs enterprises employ thousands of collectors, village investors in Nepal for at least a few seasons in the year, including hundreds of trades as well as locally utilized forest products of natural biological origins. The demand for NTFPs has grown in recent years. NTFPs provide nutrients, medicines, fodder, wood, thatch, and building equipment for rural households, including mulch and non-farm profits. The higher the demand of NTFPs, the greater the ability it is, and the greater the probability of overexploitation, as defined by Ros-Tonen (1999). The objective of this article is to document the status of NTFPs and their roles in livelihood improvement of the people in Nepal. Relevant literatures from 1992 to 2020 were collected from journal articles, books, reports, proceedings papers on current situation of Non-Timber Forest 
Products (NTFPs) and their roles in livelihood improvement and income generation. Different types of NTFPs and their export and exploitation situation were discussed in this review paper. Web pages were visited, and the relevant information was collected. Authors' experiences in NTFPs were also internalized in the paper. Finally, information collected from different sources were analyzed and presented.

\section{Forest Products in Nepal}

In the formal trade of NTFPs, the information provided by Kanel (2004) on Community forestry and $\operatorname{DoF}$ (2005, 2006 and 2007) was accumulated on the total royalties. The involvement of the forestry sector to the national GDP (Gross Domestic Products) often depends on structured trade, which excludes many facets of economic valuation for forestry-generated goods and services. In order to include a more accurate estimate of the contribution of the forestry sector to the GDP of Nepal, the Nepal Foresters Association carried out a survey to evaluate and suggest appraisal methods in Nepal. In Nepal, there are more than 700 plant species that have medicinal value, of which 238 are in active use and 150 are traded (Acharya, 2014). 30 species of which 12 are commercially cultivated and market-fostered (AEC/FNCCI, 2004; Shrestha and Das, 2008; Subedi, 2006; Luintel et al., 2004) have been prioritized by the Government of Nepal. A 1995 survey by manufacturers, merchants, and processors of NTFPs from the eastern frontier of Nepalgunj to the midwestern town shows that a total of 100 businessmen managed over 42,000 metric tons, equal to US\$26 million, with more than 100 specific products of the NTFP (Subedi, 1997). Annual shipments to India are projected to be between 10,000 to 15,000 tons of plant components of more than hundreds of species or $90 \%$ of overall trading in NTFPs (Edwards, 1996). Devkota (2006), by analyzing the royalty contribution of various forest products during the fiscal year 2002-04, illustrates that the contribution of medicinal and aromatic plants was only $3.5 \%$; that of the rest of the non-timber products such as sand and gravel was $16.5 \%$ and that of timber and fuelwood was over $80 \%$. In Nepal, the growing middle class and lifestyle changes also impact the trade-in and prospects of NTFPs. With more and more emphasis on organic way of living and use of natural products in developed countries, NTFPs are likely to be demanded and diversified further in use and commerce (Subedi, 2006).

\section{Categories of NTFPs}

The NTFPs can be grouped into two categories: consumptive and non-consumptive. Consumptive NTFPs on one hand are utilized at the personal and household level and also serve as the products sold in the market; whereas non-consumptive NTFPs on the other hand are related to the indirect benefit of sound forest management and promoting ecotourism (Hammet, 2004).NTFPs include medicinal and aromatic plants (MAPs), bamboo and rattan, dyes, fibers, papers, wild foods, soap detergents, resin, and others. The categories of NTFPs based on purposes were given in Table 1 below. 
Table 1: Categories of non-timber forest products based on their uses in Nepal

\begin{tabular}{|c|c|c|c|c|}
\hline S. No. & Category & $\begin{array}{l}\text { Terai and Siwaliks } \\
\text { (upto } 1000 \mathrm{~m} \text { height) }\end{array}$ & $\begin{array}{l}\text { Hills (1000 to } 3000 \mathrm{~m} \\
\text { height) }\end{array}$ & $\begin{array}{l}\text { Mountains (above } \\
3000 \mathrm{~m} \text { height) }\end{array}$ \\
\hline 1. & $\begin{array}{l}\text { Medicinal } \\
\text { and } \\
\text { aromatic } \\
\text { plants }\end{array}$ & $\begin{array}{l}\text { Aank, Akashbeli, } \\
\text { Amala, Ander, Asuro, } \\
\text { Bel, Barro, Batulo } \\
\text { Pate, Bhringaraj, } \\
\text { Bojho, Chiuri, Curry } \\
\text { Leaf, Dhaturo, } \\
\text { Dhayaro, Dronpuspi, } \\
\text { Ghodtapre, } \\
\text { Ghyukumari, Gujro, } \\
\text { Harro, Indrajau, } \\
\text { Indreni, Kakdsinghi, } \\
\text { Kantakari,Kauso, Khas } \\
\text { Has, Kurilo, } \\
\text { Laghupatra, Museli, } \\
\text { Neem, Pipla, } \\
\text { Rajbriksha, } \\
\text { Sarpagandha, Simal, } \\
\text { Sindhure, Tatelo, } \\
\text { Ttepati, Tulasi, Tunni }\end{array}$ & $\begin{array}{l}\text { Akarkaara, Akashbeli, } \\
\text { Chiraito, Chutro, } \\
\text { Bajradanti, Banjira, Batulo } \\
\text { Pate, Bhutkesh, Bojho, } \\
\text { Budo Okhati, Dalechuk, } \\
\text { Devdar, Dhasingre, } \\
\text { Dhatelo, Dhaturo, Dhayaro, } \\
\text { Dronpuspi, Eklebir, } \\
\text { Gamdol, Ghoda Marcha, } \\
\text { Ghyu Kumara, Guchichyau, } \\
\text { Hadchur, Indren, Jhyau, } \\
\text { Jiwanti, Kurilo, Kaladana, } \\
\text { Lauthsalla, Malagiri, } \\
\text { Pakhanved, Pudna, Satuwa, } \\
\text { Siltimur, Sugandhakokila, } \\
\text { Sugandhawal, Thulo } \\
\text { Okhati, Timur, Titepati, } \\
\text { Tulasi, Tunni }\end{array}$ & $\begin{array}{l}\text { Attis, Bhutkesh, } \\
\text { Bhuinchuk, Bish, } \\
\text { Bishma, Dhupi, } \\
\text { Dhupjadi, } \\
\text { Jatamansi, Jhyau, } \\
\text { Kakoli, Kutki, } \\
\text { Laghupatra, } \\
\text { Lauthsalla, } \\
\text { Maharangi, } \\
\text { Maikopila, } \\
\text { Ninejadi, Nirmasi, } \\
\text { Padamchal, } \\
\text { Padam Puskar, } \\
\text { Panchaaule, } \\
\text { Sarmaguru, } \\
\text { Somlata, Sunpati, } \\
\text { Talispatra, } \\
\text { Yarsagumba }\end{array}$ \\
\hline 2. & Fiber & Bhang, Babyo, Ketuki & Allo, Babiyo, Bhang & \\
\hline 3. & Paper & & Lokta, Argeli, Furkepat & \\
\hline 4. & Dyes & Bot Dhayaro & $\begin{array}{l}\text { Chutro, Jamanemanro, } \\
\text { Majitho, Okhar (husk), } \\
\text { Kafal, Dalechuk }\end{array}$ & $\begin{array}{l}\text { Padamchal, } \\
\text { Bhuinchuk }\end{array}$ \\
\hline 5. & $\begin{array}{l}\text { Bamboos, } \\
\text { Rattans, } \\
\text { Vines } \\
\end{array}$ & Bamboos, Bet & Nigalo & Nigalo \\
\hline 6. & $\begin{array}{l}\text { Wild food } \\
\text { including } \\
\text { spices, } \\
\text { culinary }\end{array}$ & $\begin{array}{l}\text { Bel, Bayar, Bhyakur, } \\
\text { Chiuri, Curry Leaf, } \\
\text { Jamun, Kadam, Kurilo, } \\
\text { Sajyon, Siplikan, } \\
\text { Tejpat }\end{array}$ & $\begin{array}{l}\text { Ainselu, Bhyakur, Gunyalo. } \\
\text { Kafal, Katush, Jhuse Til, } \\
\text { Koiralo, Kukurdaino, Lapsi, } \\
\text { Latte, Lude, Malo, Nigalo, } \\
\text { Niuro, Okhar, Siplikan, } \\
\text { Sisnu, Tarul, Tejpat, Unyu }\end{array}$ & $\begin{array}{l}\text { Banlasun, Jangali } \\
\text { Jira, Jimbu, } \\
\text { Padamchal }\end{array}$ \\
\hline 7. & Resins & & Khoye Salla & \\
\hline 8. & $\begin{array}{l}\text { Soaps/ } \\
\text { detergents }\end{array}$ & Rittha, Sikakai & Sedum spp., Pangar & \\
\hline 9. & Others & $\begin{array}{l}\text { Bhorla, Dar, } \\
\text { Chhatiwan, Khayar, } \\
\text { Pawan, Sajiwan, Sal } \\
\text { Seed, Simal, } \\
\text { Rudraksha }\end{array}$ & $\begin{array}{l}\text { Bilaune, Kaulo, Amriso, } \\
\text { Nagbeli, Rudraksha }\end{array}$ & Bhojpatra \\
\hline
\end{tabular}

(Source: Pyakurel and Baniya, 2011) 
Doi: https://doi.org/10.33002/nr2581.6853.03024

The categories of NTFPs based on altitudinal zones was given in Table 2. The NTFPs are found from tropical to temperature regions in Nepal. The species vary with altitudes of the region.

Table 2: Categories of NTFPs based on altitudinal zones in Nepal

\begin{tabular}{|c|c|}
\hline Altitudinal zone & NTFP species \\
\hline 1. Tropical(upto $1000 \mathrm{~m})$ & $\begin{array}{l}\text { Kurilo, Tulsi, Khayer, Bel, Harro, Barro, Amala, } \\
\text { Sikakai, Tendu, Sarpagandha, Neem, Haldu, Jackfruit, } \\
\text { Babul, Amaltus }\end{array}$ \\
\hline 2. Sub-tropical (1000 to $2000 \mathrm{~m}$ ) & $\begin{array}{l}\text { Lokta, Argeli, Chiraito, Wintergreen, Timur, Pipla, } \\
\text { Tejpat, Dalchini, Kurilo,Rudraksha, Ritha, Majitho, } \\
\text { Gurjo, Pushpa, Bhyakur, Bajradanti, Sugandhwal, } \\
\text { Sugadhkokila, Vasa }\end{array}$ \\
\hline $\begin{array}{l}\text { 3. Himalayan and trans-Himalayan } \\
\text { a. Temperate ( } 2000 \text { to } 3000 \mathrm{~m})\end{array}$ & Atis, Chiraito, Sugandhwal, Nirmasi, Chutro, Tilpushpi \\
\hline b. Sub-alpine (3000 to $4000 \mathrm{~m}$ ) & $\begin{array}{l}\text { Chiraito, Morels, Padamchal, Satuwa, Sunpati, Juniper, } \\
\text { Lichens, Laghupatra, Lauthsalla, Panchaunle }\end{array}$ \\
\hline c. Alpine (above4000 m) & Kutki, Jatamansi, Yarshagumba \\
\hline
\end{tabular}
(Source: Subedi, 2006)

\section{Medicinal and Aromatic Plants (MAPs)}

The use of (MAPs) medicinal and aromatic plants as supplementary food and ethnomedicine together with the potential cash income is an extremely important source of livelihoods and resilience for the poor rural people of Nepal. The NTFPs have a major potential in the MAPs subsector. This is because more than $75 \%$ of the people in Nepal use herbal drugs (Kalauni and Joshi, 2018). MAPs have expanded its contribution to the economy of Nepal, with elevated prices than forestry goods (Acharya et al., 2015; Kalauni and Joshi, 2018). MAP species is extracted unsustainably. However, a sustainable production, processing, marketing, and consumption system has good potential to provide jobs and income to thousands of Nepalese people (Ghimire and Awasthi, 2016; Kalauni and Joshi, 2018; Karki, 2017). Nepal is estimated to export around 33,000 mt of MAP products with an annual revenue amount of around 19-60 million US\$ (MoFSC, 2009). The export value increased from US\$27.49 million in 2005 to US\$ 60.09 million in 2014. Nepal on average exported 13,230 mt worth US\$ 39.34 million per year equivalent of MAP products during the last 10 years (Kalauni and Joshi, 2018) to more than 50 countries. Approximately 800 species of MAPs and non-timber forest products (NTFPs) are used for subsistence livelihoods and over 160 species for commercial trade (Karki, 2004a; Karki, 2004b; DoF, 2008; GoN, 2009). Over $90 \%$ of the NTFPs exports are dispatched to India in crude forms, providing lesser benefits to the local and national economy compared to its potential benefits if value-adding processing was done within the country (ANSAB and EWW, 2000). Nepal, however, lacks the technical, financial, and guaranteed market capabilities for processed NTFPs. For instance, the secondary source of income of rural people is NTFPs, non-timber forest products (NTFPs) form the secondary source of income in most parts of Nepal; it provides 35-50\% total income of a household in Karnali zone (Parajuli, 2005; GIZ, 2011). It is estimated that the contribution of bamboo to total household income is 12\% (Karki, 1995). The list of some medicinal plants found in Nepal is given in Table 3. 
Doi: https://doi.org/10.33002/nr2581.6853.03024

Table 3: List of some medicinal plants found in Nepal

\begin{tabular}{|c|c|c|c|c|c|}
\hline SN & Trade name & Botanical name & $S N$ & Trade name & Botanical name \\
\hline 1 & Amala & Phyllanthus emblica & 26 & Bhojpatra & Betula utilis \\
\hline 2 & Bhorla Bokra & Bauhinia vahlii & 27 & Bhutkesh & Jurenia dolomiea \\
\hline 3 & Kurilo & Asparagus racemosus & 28 & Dhupipat & Juniperus species \\
\hline 4 & Barro & Terminalia belerica & 29 & Guchhi & Morchella conica \\
\hline 5 & Bojho & Acorus calamus & 30 & Katush & Castanopsis species \\
\hline 6 & Jiwanti & Ephemerantha macarei & 31 & Gheukumari & Aloe vera \\
\hline 7 & Lokta & Daphne bholua & 32 & Kutki & $\begin{array}{l}\text { Neopicrorhiza } \\
\text { scrohpularoflora }\end{array}$ \\
\hline 8 & Somlata & Ephedra gerardiana & 33 & Nirmansi & $\begin{array}{l}\text { Delphinium } \\
\text { denundatum }\end{array}$ \\
\hline 9 & Sugandhwal & Valeriana wallichii & 34 & Setak chini & Moringa oleifera \\
\hline 10 & Bajradanti & Potentilla fruticosa & 35 & Siltimur & Litsea cubeba \\
\hline 11 & Kauloko bokra & Persea species & 36 & Thingresalla & Abies spetabilis \\
\hline 12 & Pakhanbed & Bergenia ciliata & 37 & Aank bhuwa & Calotropis gigantea \\
\hline 13 & Datiwan & Achyranthes bidentata & 38 & Yarsagumba & Cordyceps sinensis \\
\hline 14 & Rittha & Sapindus mukorossi & 39 & Kachur & Curcuma aromatica \\
\hline 15 & Tejpat & Cinnamomum tamala & 40 & Bhyakur & Dioscorea species \\
\hline 16 & Timur & Zanthoxylum armatum & 41 & Bishjara & Aconitum species \\
\hline 17 & Chatiwan & Alstonia scholaris & 42 & Chiraito & Swertia chirayita \\
\hline 18 & Chyau & Mushroom & 43 & Jhyau & Lichen species \\
\hline 19 & Kakarsingi & Pistachia chinensis & 44 & Dalchini & Cinnamomum tamala \\
\hline 20 & Satuwa & Paris polyphylla & 45 & Daruhaldi & Mahonia nepalensis \\
\hline 21 & Chutro & Berberia asiatica & 46 & Tite pati & Artemisia dubia \\
\hline 22 & Neem & Azadirachta indica & 47 & Ghod tapre & Centella asiatica \\
\hline 23 & Pani amala & Nephrolepsis cordifolia & 48 & Tulsi & Ocimum tenuiflorum \\
\hline 24 & Sisno & Urtica parviflora & 49 & $\begin{array}{l}\text { Laali } \\
\text { Gurans }\end{array}$ & $\begin{array}{l}\text { Rhododendron } \\
\text { arboreum }\end{array}$ \\
\hline 25 & Bayer & Ziziphus mauritiana & 50 & Rudilo & $\begin{array}{l}\text { Pogostemon } \\
\text { benghalensis }\end{array}$ \\
\hline
\end{tabular}

(Source: Kunwar et al., 2006)

\section{NTFPs in Livelihoods}

Non-timber forest products (NTFPs) have become increasingly recognized to support resilience and livelihood enhancement of rural communities in Africa, Asia, and elsewhere in developed as well as developing countries (Campbell and Luckert, 2002; Mukul et al., 2010; Kar and Jacobson, 2012; Cavendish, 2000). A livelihood is sustainable, resources, and activities necessary to provide the livelihood (DFID, 1999), both material and immaterial social activities and resources. Traditionally and fundamentally MAPs and NTFPs are correlated with rural peoples' livelihoods. NTFPs have the potential to play a vital role in reducing seasonal and long-term malnutrition and food insecurity. Local people have indigenous knowledge of the available forest resources used for their food security in combination with agricultural production. Local people sometimes use these sources for income generation, which provides an opportunity for alternative livelihood options as 
well (IUCN, 2001). In Nepal's forest policies and cumulative development planning, NTFPs have been extremely important. Interim Programme (2007/08 to 2009/10), Policies and Services of the current administration, 2008-09 fiscal expenditure, Political Participation Manifestations, Donor Reports, The Poverty Reduction Strategy Paper (PRSP) including country strategy papers as well as the program materials from bilateral projects and INGOs, the documents of Community Forestry Users Groups (CFUGs) recently highlighted the importance of NTFPs for conservation. In recent decades, with growing concern about conservation, together with rural poverty and sustainable development, researchers, as well as conservation and development organizations, made efforts to bring NTFPs at the centre of discourse (Belcher, Perez and Achdiawan, 2005; Subedi, 2006). As a result, the governments of several developing countries, including Nepal, received pressure to formulate policies that promoted NTFPs.

\section{NTFPs and Income Generation}

In household economies of rural societies residing in or close the forest, NTFPs have three primary functions. Initially, NTFPs support the needs of households for their subsistence and consumption for energy, nutrition, medicine, and construction, etc. Second, in periods of recession (e.g. revenue losses from certain sources of production, for example, crop failure), they are seen as a defense net and thirdly, certain NTFPs have daily cash (Angelsen and Wunder, 2003; Cavendish, 2002). The importance of NTFPs (utilization and monetary value) may also be significantly greater than timber production, or land conversion to pastureland or farmland (Rogue, 1992). There is also growing evidence that local and wider-scale commercialization of NTFPs is increasing in many regions, providing cash income to numerous households (Welford and le Breton, 2008; Cunningham, 2011). Research by Olsen (1998) reported that, during the fiscal year 1993/94, 470,000 Nepalese households were actively involved to collect economically important NTFPs species. In terms of employment, ANSAB (Asia Network for Sustainable Agriculture and Bioresources) estimated that around 189,000 people work in the NTFPs sub-sector (MSFP, 2014). It is widely estimated that they draw between 15 and 50\% of their household income from the sub-sector (APAARI/FAO, 2013; Edwards, 1996; MSFP, 2014). A proper investment environment can create employment opportunities for local people reducing the heavy flow of youth migration to cities and foreign countries for jobs. This will also reduce poverty by providing income raising opportunities locally (GIZ, 2015; IUFRO, 2012). The list of some NTFPs having potentiality for developing enterprise is given in Table 4.

Table 4: List of NTFPs having potential for enterprise development

\begin{tabular}{l|l|l}
\hline S.N. & Local Name & Scientific Name \\
\hline 1 & Jatamansi & Nardostachys grandiflora D.C. \\
\hline 2 & Neem & Azadirachta indica A. Juss. \\
\hline 3 & Rittha & Sapindus mukorossi Gaertn. \\
\hline 6 & Guchichyau & Morchella conica \\
\hline 7 & Timur & Zanthoxylum armatum D.C. \\
\hline 8 & Dalchini & Cinnamomum tamala (Buch.-Ham) \\
\hline 9 & Bet & Calamus tenuis \\
\hline
\end{tabular}


Doi: https://doi.org/10.33002/nr2581.6853.03024

\begin{tabular}{l|l|l}
\hline 10 & Satawari & Asparagus racemosus Wild. \\
\hline 11 & Sabai Grass & Eulaliopsis binata \\
\hline 12 & Sal leaves & Shorea robusta \\
\hline 13 & Sugandhawal & Valeriana jatamansi jones \\
\hline 14 & Atis & Delphinium himalayai Munz. \\
\hline 16 & Pipla & Piper longum Linn. \\
\hline 17 & Kutki & Picrorhiza scrophulariflora Pennell \\
\hline 18 & Chiraito & Swertia chiraita (Roxb. Ex Flem, Karst) \\
\hline 20 & Amala & Phyllanthus emblica L. \\
\hline 21 & Barro & Terminalia bellirica (Gaertn.) Roxb. \\
\hline
\end{tabular}

(Source: Jayaswal, 2020)

\section{Export of NTFPs}

In Nepal, there are several local companies based on NTFPs, particularly basket making from bamboo. Daphne bark to produce lokta paper and Girardinia diversifolia for the manufacturing of alloy paper are some classical examples. NTFPs also provide a limited range of raw materials for industry in Nepal. Of most significance is resin tapping from Pinus roxburghii; katha extraction, a dye from the heartwood of Acacia catechu, and paper from Sabai grass (Eulalopsis binata). In terms of the volume and value of trade in NTFP, the Government of Nepal records indicates the growing trend in formal export trade. The trade volume increased from 3,350 tons in 1990 to 13,000 metric tons (mt) in 2010 (NPC, 2011) and to more than 33,000 mt in 2012 (Karki, 2012; MoFSC, 2009). In 2010 the export earnings from the NTFPs were estimated at between US\$13 million and US\$ 26 million (GoN (2009), as stated by Karki (2012). The annual value expansion of the NTFP between 1995 and 2002 was approximated to be around 5.5\% per year (Subedi, 2006). According to an assessment undertaken out by ANSAB (MSFP, 2015), Nepal's NTFP exports rose from 2.76 million US dollars in 1992 to 59 million US dollars in 2012. The analysis showed a rise of about 4\% a year between 1992 and 2002 in the share of NTFPs in the overall export volume, which doubled (MSFP, 2014). The findings suggest the optimistic growth trend in Nepal's NTFP market, with annual rises in the amount of NTFP traders and industries every year (MSFP, 2014). This pattern also enhances NTFPs' burgeoning economic, social, and ecological significance (IUFRO, 2012).

In Baitadi, Bista and Webb (2006) documented an NTFP contribution of $11.7 \%$. In Baitadi, Darchula, and Dadeldhura, Kunwar et al. (2013) approximated 20\% sales revenue. Olsen and Larsen (2003) estimated 12\% contribution of MAPs in higher elevations in Nepal. Jadibuti Association of Nepal (JABAN) issues the recommendation letter to District Forest Office, Banke (Nepalgunj) for MAPs export and they have recommended to export 4,596 tons of MAPs in FY 2014/15 (JABAN, 2015), demonstrating that Nepalgunj is still the most favored transit city in Nepal in terms of MAPs export to India. 14 out of 17 MAPs were exported to India and only three (Ganoderma lucidum, Paris polyphylla and Dendrobium sp.) were exported to China via Kathmandu. Among the NTFPs and medicinal and aromatic plants (MAPs), tejpat (Cinnamom 
umtamala), timur (Xanthoxylum aramatum), rittha(Sapindus mukorossi), ginger, honey and large cardamom are extensively grown as agro-forestry crops in Nepal. Average annual export of large cardamom from Nepal is about $5959 \mathrm{mt}$ (TEPC, 2015). Although large cardamom has been one of the largest exports agro-products from Nepal, it has been facing stagnant demand in the international market because of limited value addition due to lack of modern processing and storage facility (NTIS, 2016). An approximate 20,000 households are participating in production, processing and marketing of timur (Xanthoxylum aramatum) in Nepal. The value chain of timur is estimated to generate around US\$ 1 million revenue to the government. However, collection and processing practice is primitive and the process is hard drudgery to women, children, and poor people as they use their traditional knowledge and tools to gather and process Timur (Prakrit, 2007; Karki, 2004; MOA/SNV, 2011).

Dadeldhura district, located in Far-Western Nepal, is a center for the trade of medicinal and aromatic plants, including Ganoderma products. tejpat (Cinnamom umtamala), resin (Pinus roxburghii) and rittha (Sapindus mukorossi), and have been harvested from that area. Resin is processed from both national forests and community managed forests. In the five years (FY 2069/070 to FY 2073/074), resin extraction revenue is about NRs. 980,981 (GoN, 2018). Dadeldhura's Forest Division also allows Ganoderma to be gathered in national and community forests with NRs of $5 / \mathrm{kg}$. The gathering of this specific species was ascertained by a local trader as observed. The local trader incorporates 5-7 people during the monsoon season to harvest the species from the high mountain areas. The local traders then buy from collectors at NRs. 1,000/kg. The central retailer is liable for manufacturing involving washing, drying sorting, and packaging. Then a local seller sells it for NRs 4,000/kg to the dealer in Kathmandu and then sells it in NRs $10,000 / \mathrm{kg}$ to Chinese traders. The local trader has been involved in the business for 5 years and has sold around 1.5 tons of species from the Dadeldhura district. Ganoderma lucidum (family Ganodermataceae), Polypore basidiomycetous fungi, has a long history of use for promoting health and longevity in China, Japan, and other Asian countries. In Dadeldhura district, it is collected by the local communities from the trunks of living or dead trees, mainly from oak forests.

Exact contribution of the NTFP sub-sector to Nepal's national economy is difficult to establish for different sources of data indicate different levels of contribution (MSFP, 2014; FNCCI-AEC/ NEHHPA, 2012). This is mainly because available data and information are not consistent and refer to a wide range of wild extracted, domesticated, cultivated, and processed goods or products. But it can be safely argued that NTFP sub-sector is a major source of rural employment and income for Nepalese farmers and a major source of revenue for the national and local economies (MSFP, 2014; Karki, 2012; Karki, 2015).

\section{Exploitation of NTFPs}

NTFPs are cultivated because of their medical values from ancient times. Early harvest and overcollection are the cause of the deterioration of NTFP species. People who are pressured by food shortages must earn money by collecting NTFPs. There is also competition among the primary collectors to collect more NTFPs. In addition, local traders sometimes encourage primary collectors to collect more NTFPs, especially for the most sought-after species on the market. NTFP species are often overexploited because of their higher market values (Edward, 1994; Karki, 1996; Sharma, 1996). The causes of degradation can be associated with an unclear definition of property rights, lack of knowledge on conservation, and increasing market demand (Subedi and Bhattarai, 1998). 
Doi: https://doi.org/10.33002/nr2581.6853.03024

There is a need to reinstitute local institutions for the sustainable collection of economically valuable NTFPs species.

\section{Conclusions}

Nepal is rich in NTFPs, which plays an important role in increasing rural income. NTFP enterprises are a potential way to contribute to poverty alleviation. The promotion and domestication of NTFPs, proper policy frameworks for harvesting, and better processing techniques are critical to ensuring food security, poverty reduction, and livelihood improvement. There is a need to make concerted efforts in releasing barriers of marketing and trade in NTFPs, and supporting and facilitating individuals and communities to harness benefits from NTFPs. Formulation of the sitespecific and species-specific plans for the conservation, management, and utilization of the NTFP resources is necessary. Local communities should be empowered for growing and marketing of NTFPs.

\section{References}

Acharya, C. (2014). Non-Timber Forest Product and its Trade in Nepal. https://www.slideshare.net/acchhabi/non-timber-forest-in-nepal

Acharya, R. P., Dahal, S., Kunwar, R. M., Sharma, R., and Baral, S. (2015). Medicinal and aromatics plants in a far western Nepal: A sustainable livelihoods analysis. Hartmann and Weipert: Biodiversität und Naturausstattungim Himalaya V. Erfurt 2015. https://www.researchgate.net/publication/299676190.

AEC/FNCCI (Agro Enterprise Center (AEC)/ Nepalese Chambers of Commerce and industry (FNCCI) (2004). Trade pattern of non-timber forest products (NTFPs) in Jumla, Surkhet and Nepalgunj: appropriate policy measures for business and trade enhancement, Federation of Nepalese Chambers of Commerce and Industry, Agro Enterprise Center.

Ahenkan, A. and Boon, E. (2011). Commercialization of non-timber forest products in Ghana: processing, packaging and marketing. Food Agri. and Environ, 8: 962-969.

Angelsen, A. and Wunder, S. (2003). Exploring the Forest-Poverty Link: Key Concepts, Issues and Research Implications. CIFOR, Bogor, Indonesia. pp. viii, 58p

Angelsen, A., Jagger, P., Babigumira, R., Belcher, B., Hogarth, N.J. and Bauch, S. (2014). Environmental income and rural livelihoods: a global comparative analysis. World Development, 64: 12-28.

ANSAB and EWW (Asia Network for Sustainable Agriculture and Bioresources (ANSAB), Enterprise Works Worldwide (EWW). (2000). Enterprise development for natural products. Kathmandu, Nepal: ANSAB.

APAARI/FAO (Asia - Pacific Association of Agricultural Research Institutions (APAARI), Food and Agriculture Organization (FAO) (2013). Proceeding and Recommendation of the Expert Consultation on Authors: M.B. Karki, Nirmal Bhattarai; presented in 2012 IUFRO Conference Division 5: December 2-3, 2013. Organized by the FAO Regional Office and the Asia Pacific Association of Agriculture Research Institute (APAARI).

Banjade, M.R. (2012). Discourse and discursive practices over timber in Nepal. Journal of Forest and Livelihood, 10(1): 58-73.

Belcher, B., Perez, M. R. and Achdiawan, R. (2005). Global pattern and trends in the use and management of commercial NTFPs: Implications for livelihoods and conservation. World Development, 33(9): 1435-1452. 
Doi: https://doi.org/10.33002/nr2581.6853.03024

Bhattarai, N.K. (1997). Biodiversity-people interface in Nepal, medicinal plants for forest conservation and health care. FAO, UN, Rome, Italy: NWFP bulletin, 11.

Bishnu Prasad Sharma, B.P., Lawry, S., Paudel, N.S., McLain, R. Adhikary, A. and Banjade, M.R. (2020). Operationalizing a Framework for Assessing the Enabling Environment for Community Forest Enterprises: A Case Study from Nepal. Small-scale Forestry (2020) 19:83-106 https://doi.org/10.1007/s11842-020-09433-w

Bista, S. and Webb, E.L. (2006). Collection and marketing of non-timber forest products in the Far Western Hills of Nepal. Environmental Conservation, 33(3): 244-255.

Campbell, M.B. and Luckert, K.M.E. (2002). Uncovering the Hidden Harvest: Valuation Methods for Woodland and Forest Resources. Earthscan Publications Ltd., London

Cavendish, W. (2000). Empirical regularities in the poverty-environment relationship of rural households: evidence from Zimbabwe. World Development, 28: 1979-2003.

Cavendish, W. (2002). Quantitative methods for estimating the economic value of resource use to rural households. Uncovering the Hidden Harvest: Valuation Methods for Woodland and Forest Resources. Earthscan publications Ltd., London.

Chandrashekharan, D. (1998). NTFPs, institutions and income generation in Nepal: lessons from community forestry. A report submitted to ICIMOD, Kathmandu. pp. 45.

Cocks, M.L. and Wiersum, K.F. (2003). The significance of plant diversity to rural households in the Eastern Cape province of South Africa. For. Trees Livelihoods, 13: 39-58

Cocksedge, W. (2006) Incorporating non-timber forest products into sustainable resource management: an overview for resource managers. Royal Roads University, Victoria

Cunningham, A.B. (2011). Non-timber products and markets: Lessons for export-oriented enterprise development from Africa, in non-timber forest products in the global context, eds. S.E. Shackleton, C.M. Shackleton and P. Shanley (Springer, Heidelberg), 83-106. doi: https://doi.org/10.1007/978-3-642-17983-9_4 .

Devkota, B.P. (2006). Medicinal and non-timber forest products: basis for social and economic development. In: Shrestha, R., Kandel, B.R. and Devkota, B.P. (Eds.), Hamro Ban, Kathmandu: Department of Forest

DFID (Department for International Development) (1999). Sustainable Livelihoods Guidance Sheets.

DoF (Department of Forest) (2005). Hamro Ban, annual report of the Department of Forests for FY 2060/61. Kathmandu: Department of Forest.

DoF (Department of Forest) (2006). Hamro Ban, annual report of the Department of Forests for FY 2061/62. Kathmandu: Department of Forest.

DoF (Department of Forest) (2007). Hamro Ban, annual report of the Department of Forests for FY 2062/63. Kathmandu: Department of Forest.

DoF (Department of Forest) (2008). Hamro Ban. Department of Forests, Ministry of Forests and Soil Conservation, Government of Nepal. http://www.floraofnepal.org. Cited on January 3, 2017.

Edwards, D.M. (1994). Non-timber forest products and community forestry. Kathmandu: NUKCFP.

Edwards, M. D. (1996). The trade in non-timber forest products from Nepal. Mountain Research and Development, 16(4): 383-394.

Endamana, D., Angu, K.A., Akwah, G.N., Shepherd, G. and Ntumwel, B.C. (2016). Contribution of non-timber forest products to cash and non-cash income of remote forest communities in Central Africa. Int. For Rev, 18(3): 280-295. 
FAO (Food and Agriculture Organization). (1995). Planning for sustainable use of land resources: Towards a new approach: Land and Water Bulletin 2, Rome, Italy: 53 p.

FNCCI-AEC/NEHHPA (Federation of Nepalese Chamber of Commerce and Industries (FNCCI)Agro Enterprise Centre (AEC) / Nepal Herbs and Herbal Products Association (NEHHPA). (2012). NTFPs/ MAPs business promotion strategy (2012 to 2016) from private sector perspective. Kathmandu: FNCCI

Ghimire, S. K. and Awasthi, B. (2016). Export of medicinal and aromatic plant materials from Nepal. Journal of Plant Science, 10: 24-32.

Giri, T.K., Bhattacharya, P. and Santra, S.C. (2001). Ecology and economy of NTFPs in village life - a case study from Bankura district in West Bengal, India. Annals of Forestry, 9(1): 116.

GIZ (The Deutsche Gesellschaft für Internationale Zusammenarbeit). (2011a). Medicinal and aromatic plants: poverty impact assessment of proposed trade support measures in Nepal's MAPs sector. Kathmandu: GIZ.

GIZ (The Deutsche Gesellschaft für Internationale Zusammenarbeit). (2011b). Promoting exports of medicinal and aromatic plants (MAPs) and essential oils from Nepal. Areport. GIZ, 2011, Kathmandu.

GIZ (The Deutsche Gesellschaft für Internationale Zusammenarbeit). (2015). Nepalese honey: potential and challenges in export. a report. GIZ, 2015, Kathmandu.

GoN (Government of Nepal). (2009). Nepal forestry outlook study. Asia-Pacific forestry sector outlook study II.

GoN (Government of Nepal). (2014). Nepal National Biodiversity Strategy and Action Plan (NBSAP) (2014-2020). Ministry of Forests and Soil Conservation, Singh Durbar, Kathmandu Nepal.

GoN (Government of Nepal). (2018). Nepal's sixth national report to the convention on biological diversity. Ministry of Forests and Environment (MoFE), Singha Durbar, Kathmandu, Nepal December 2018.

Hammet, A.L. (2004). Non-timber forest products: profits and panacea. In: A synthesis report on the current status of NTFPs in the Terai region of Nepal. MOFSC, Kathmandu. Nepal.

IUCN (International Union for Conservation of Nature). (2001). The Role of Forest Food Resources in village Livelihood Systems: a study of three village in salavan province, Lao PDR.

IUFRO (International Union of Forest Research Organizations) (2012). Enhancing the contribution of non-timber forest products in supporting green economy and sustainable development in mountain countries. Keynote paper (KN04).

JABAN (Jadibuti Association of Nepal). (2015). Official export data for FY 2017/072. Jadibuti Association of Nepal, Nepalgunj, Nepal.

Jayaswal, M.L. (2020). Experiences of the non-timber forest products (NTFP) based enterprise development in Nepal. http://www.fao.org/3/y4496e/Y4496E10.htm

Kalauni, D., and Joshi, A. (2018). Status of medicinal and aromatic plant (MAPs) and socioeconomic influence in Nepalese livelihood-a review research article. ACTA Scientific.

Kanel, K.R. (2004). Twenty Four Years of Community Forestry: contribution to millennium development goals. In: Kanel, K.R., Matherma, P., Kandel, B.R., Niraula, D.R., Dharma, A.R. and Gautam, M. (Eds.), Proceedings of the fourth national workshop on community forestry, 4-6 August, 2004, Kathmandu, Nepal: Community Forestry Division, Department of Forest. 
Kar, S.P. and Jacobson, M.G. (2012). NTFP income contribution to household economy and related socio-economic factors: Lessons from Bangladesh. Forest Policy and Economics, 14: 136142

Karki, M. (2004a). Certification and marketing strategies for sustainable commercialization of medicinal and aromatic plants in South Asia. (Rotorua, New Zealand: IUFRO all division 5 conference on forest products, 2003).

Karki, M. (2004b). Institutional development process in medicinal plants sector: a case study of Nepal. In: Thomas, Y.Y. and Karki, M. (Eds.), Proceedings of wise practices in sustainable management of Himalayan medicinal plants (Kathmandu: People and Plants International and International Development Research Centre).

Karki, M. (2012). Sustainable mountain development 1992, 2012, and beyond: Rio+20 assessment report for the Hindu Kush Himalaya region, a joint publication of ICIMOD, Kathmandu.

Karki, M. (2015). Challenges, opportunities and trade off in commercialization of medicinal and aromatic plants in South Asian Region. https://www.academia.edu/12863952/CHALLENGES_OPPORTUNITIES_AND_TRADEOFFS_IN_COMMERCIALIZATION_OF_MEDICINAL_AND_AROMATIC_PLANTS_I N_SOUTH_ASIA_REGION.

Karki, M.B. (1995). National Bamboo and Rattan Information Database, Nepal. Pokhara: Tribhuvan University, Institute of Forestry.

Karki, M. B. (2017). Challenges, opportunities and trade-offs in commercialization of medicinal and aromatic plants in South Asian Region. Invited paper presented at the workshop on current challenges and recommendations; Government of India; New Delhi, India.

Karki, S. (1996). Investigating non -timber forest products (NTFPs) opportunities in Nepal. Kathmandu: Nepal Australia Community Forestry Project. Kathmandu and the Swiss Development Cooperation (Kathmandu: International Centre for Integrated Mountain Development, 2011). Kathmandu. Ministry of Forest and Soil Conservation, Government of Nepal.

Kunwar, R. M., Mahat, L., Acharya, R. P. and Bussmann, R. W. (2013). Medicinal plants, traditional medicine, markets and management in far-west Nepal. Journal of Ethnobiology and Ethnomedicine, 9: 24.doi: https://doi.org/10.1186/1746-4269-9-24

Kunwar, R.M., Nepal, B.K., Kshhetri, H.B., Rai, S.K. and Bussmann, R.W. (2006). Ethnomedicine in Himalaya: A case study from Dolpa, Humla, Jumla and Mustang districts of Nepal. Journal of Ethnobiology and Ethnomedicine, 2: 27. doi:https://doi.org/10.1186/1746-4269$2-27$.

Luintel, H., Banjade, M.R., Pandey, R.K. and Neupane, H.R. (2004). Issues of sustainable nontimber forest product management and a way forward. In: Kanel, K.R., Mathema, P., Kandel, B.R., Niraula, D.R., Sharma, A.R., and Gautam, M. (Eds.), Proceeding of the fourth national workshop on community forestry. Kathmandu: Department of Forest. Pp. 42-47.

MOA/SNV (Ministry of Agriculture (MOA, SNV Netherlands Development Organization) (2011). Value chain analysis of Timur, high value agriculture project in hills and mountain area (HVAP), Ministry of Agriculture Development/SNV. IFAD project.

MoFSC (Ministry of Forest and Soil Conservation) (2009). Working paper no. APFSOSII/WP/2009/05. Agriculture Organization of the United Nations Regional Office for Asia and the Pacific, Bangkok, 8 pp.

MoFSC (Ministry of Forest and Soil Conservation). (2009). Nepal fourth national report to the convention on biological diversity. 
Doi: https://doi.org/10.33002/nr2581.6853.03024

MSFP (Multi Stakeholder Forestry Programme). (2014). Services support unit (SSU), Forestry complex, Babarmahal, Nepal. www.msfp.org.np.

Mukul, S.A., Uddin, M.B., Rashid, A.Z.M.M., and Fox, J. (2010). Integrating livelihoods and conservation in protected areas: understanding role and stakeholders' views on the prospects of non-timber forest products, A Bangladesh case study. International Journal of Sustainable Development and World Ecology, 17(2): 180-188.

NPC (National Planning Commission). (2011). Three year plan approach paper (2010/112012/13). Government of Nepal, National Planning Commission.

NTIS (Nepal Trade Integration Strategy). (2016). Nepal Trade Integration Strategy 2016. GON, MOC, Kathmandu.

Olsen, C.S. (1998). The trade in medicinal and aromatic plants from central Nepal to northern India. Economic Botany, 52(3): 279-292.

Olsen, C.S. and Larsen, H.O. (2003). Alpine medicinal plant trade and Himalayan mountain livelihood strategies. Geographical Journal, 169: 243-254.

Parajuli, D. (2005). Potentiality in enterprise development of Nepalese MAPs and other NTFPs: a call for multidimensional investment, synthesis of seminar preparation and discussions during first national trade show and seminar on herbs, herbal products and spices. November 12-14, 2005. Nepalganj. Sahakarya project, Canadian Center for International Studied and Cooperation (CECI) Kathmandu. 2005, pp. 22-24.

Paudel, G. (2014). Analysis of equity, poverty and sustainability aspects of community forests of Nepal. VIKAS, 36(1): 89-96.

Paudel, G. (2015). Forest resource income variation in mid-hills of Nepal: a case study from two CFUGs of Parbat district, Nepal. International Journal of Environment, 4(3): 1-10.

Prakrit. (2007). Sugandhit Tel Niryatma Dekhiyika Samasyaharu (Problems in aromatic oil export), (in Nepali). Prakrit, 3(1): 9-15.

Pyakurel, D. and Baniya, A. (2011). NTFPs: Impetus for Conservation and Livelihood support in Nepal. A reference book on ecology, conservation, product development and economic analysis of selected NTFPs of Langtang area in the sacred Himalayan landscape. WWF Nepal.

Rogue, C. (1992). Creating conditions for incentives for local biodiversity conservation. In: Courrier, K. (ed.), Global Biodiversity Strategy (pp. 79-95). World Resource Institute, IUCN and UNEP.

Ros-Tonen, M.A.F. (1999). Introduction: NTFP research in the Tropenbos programme. In: Tropenbos (1999). NTFP research in the Tropenbos programme: results and perspectives. Tropenbos Foundation, Wageningen, the Netherlands.

Shackleton, C. M., and Pullanikkatil, D. (2018). Considering the links between non-timber forest products and poverty alleviation, in moving out of poverty through using forest products: personal stories, Pullanikkatil, D. and Shackleton, C.M. (eds) (Heidelberg: Springer), 1528. doi: https://doi.org/10.1007/978-3-319-75580-9_2

Sharma, P. (1996). Non-wood forest products and integrated mountain development: Observations from Nepal. Business seminar on medicinal herbs, essential oils and other non-timber forest products, Kathmandu, DEG/NGCCI. 11 pp.

Shrestha, P.R. and Das, P.K. (2008). Critical review of policy issues and strategic vision related to sustainable harvesting, transportation and trade of NTFP in Nepal. A paper presented in the national workshop on 'Non-timber Forest Products and Medicinal Plants based Enterprise Development: Opportunities and Challenges’ Organized by Nepal Foresters’ Association, 
20 February 2008. Kathmandu: Medium Enterprise Development Program, UNDP and Government of Nepal.

Subedi, B.P. and Bhattarai N.K. (1998). Community managed enterprise: participation of rural people in medicinal and aromatic plants conservation and use. A paper prepared for the international conference on medicinal plants, February 16-20, 1998, Bangalore, India.

Subedi, B.P., Ghimire, P.L., Koontz, A., Khanal, S.C., Katwal, P., Sthapit, K.R. and Mishra, S.K. (2014). Private Sector Involvement and Investment in Nepal's Forestry: Status, Prospects and Way Forward. Multi Stakeholder Forestry Programme (MSFP)- Service Support Unit, Babarmahal, Kathmandu, Nepal.

Subedi, B.P. (1997). Utilization of non-timber forest products: issues and strategies for environmental conservation and economic development. A theme paper for the workshop on the utilization of NTFPs for environmental conservation and economic development in Nepal, March 29, 1997, Kathmandu: Asia Network for Small Scale Bio-resources.

Subedi, B.P. (2006). Linking plant-based enterprises and local communities to biodiversity conservation in Nepal Himalaya. Adroit Publishers, New Delhi.

TEPC (Trade and Export Promotion Center). (2015). Ministry of Commerce, Foreign Trade Statistics of Nepal, Kathmandu, Nepal.

Vedeld, P., Angelsen, A., Bojö, J., Sjaastad, E. and Kobugabe B. G. (2007). Forest environmental incomes and the rural poor. Forest Policy Econ., 9: 869-879. doi: https://doi.org/10.1016/j.forpol.2006.05.008

Welford, L. and le Breton, G. (2008). Bridging the gap: Phyto trade Africa's experience of the certification of natural products. Forest, Trees and Livelihoods, 18: 69-79. doi: https://doi.org/10.1080/14728028.2008.9752618 